\title{
PENGARUH PEMBELAJARAN TGFU DAN KOOPERATIF TERHADAP HASIL BELAJAR KETERAMPILAN DASAR SEPAKBOLA DENGAN KEMAMPUAN MOTORIK TINGGI DAN KEMAMPUAN MOTORIK
}

\author{
Luqman Hakim \\ uman.luqman@gmail.com \\ STKIP Subang
}

\begin{abstract}
The purpose of this study examine the influence TGFU and Cooperative learning model as well as motor skills to learn results of football basic skills. The learning model Teaching Games for Understanding and Cooperative learning grouped by high and low of motor skills. The method used in this study using an experimental method with $2 \times 2$ factorial design. The study was conducted in Muhammadiyah Kab. Garut junior high school. The population is all class VIII students of Muhammadiyah junior high school. The sampling technique used in this research is purposive random sampling. The sample in this study amounted to 48 students were divided into 4 groups. Instruments in this study include: (1) Barrow mototr ability test to measure motor skills, (2) Test of football basic skills. ANOVA analysis results indicate, cooperative learning and TGFU model give influence on the learn result the basic skills of football. There is interaction between the learning model and motor ability of football basic skills. TGFU learning model at a high level motor skills provide better influence to learn result of football basic skills. Cooperative learning model is better than the TGFU at a low level of motor skills to learn result of football basic skills.
\end{abstract}

Keywords: TGfU, Cooperative Learning, Motor Ability, Football Basic Skills.

\begin{abstract}
ABSTRAK
Tujuan dari penelitian ini adalah untuk menguji pengaruh model pembelajaranTGFU dan Kooperatif serta kemampuan motorik terhadap hasil belajar keterampilan dasar sepakbola. Model pembelajaran Teaching Games for Understanding dan Cooperative learning dikelompokan berdasarkan kemampuan motorik tinggi dan rendah. Metode yang digunakan dalam penelitian ini menggunakan metode eksperimen dengan desain faktorial 2x2. Penelitian dilakukan di SMP Muhamadiyah Kab. Garut. Populasi adalah seluruh Siswa SMP Muhamadiyah kelas VIII. Teknik sampling yang digunakan dalam penelitian ini adalah purposive random sampling. Sampel dalam penelitian ini berjumlah 48 siswa yang dibagi menjadi 4 kelompok. Instrumen dalam penelitian ini antara lain: (1) barrow mototr ability test untuk mengukur kemampuan motorik, (2) tes kemampuan dasar sepakbola. Hasil analisis anova menunjukan, model pembelajaran TGFU dan Kooperatif memberikan pengaruh terhadap hasil belajar keterampilan dasar sepakbola. Terdapat interaksi antara model pembelajaran dan motor ability terhadap keterampilan dasar sepakbola. Model pembelajaran TGFU pada tingkat kemampuan motorik tinggi memberikan pengaruh yang lebih baik terhadap hasil belajar keterampilan dasar sepakbola. Model pembelajaran Kooperatif lebih baik dari pada TGFU pada tingkat kemampuan motorik rendah terhadap hasil belajar keterampilan dasar sepakbola.
\end{abstract}

Kata kunci: TGfU, Kooperatif, Kemampuan Motorik, Keterampilan dasar sepakbola. 


\section{A. Pendahuluan}

Pendidikan

jasmani

merupakan bagian integral dari pendidikan secara keseluruhan, bertujuan untuk mengembangkan aspek kebugaran jasmani, keterampilan gerak, keterampilan berfikir, keterampilan sosial, penalaran, stabilitas emosional, tindakan moral, aspek pola hidup sehat dan termasuk di dalamnya pengenalan lingkungan bersih melalui aktivitas jasmani, olahraga dan kesehatan terpilih yang direncanakan secara sistematis dalam rangka mencapai tujuan pendidikan nasional. "Pendidikan Jasmani sebagai suatu proses pembinaan manusia yang berlangsung seumur hidup" (Munasifah, 2008, hlm. 1). Pembelajaran Pendidikan jasmani di sekolah diintegrasikan untuk membuat anak senang bergerak dan bermain. Dengan pembelajaran berbagai aktivitas pendidikan jasmani, diharapkan kemampuan motorik, kognitif dan apektif siswa semakin berkualitas.

Apabila dilihat dari ruang lingkup mata pelajaran pendidikan jasmani salah satunya adalah permainan dan olahraga dan permainan sepakbola merupakan salah satu permainan yang banyak diminati siswa di sekolah. Pada proses pembelajaran di lapangan, setiap siswa tentunya memiliki kemampuan bermain sepakbola yang berbeda-beda. Ada yang memiliki keterempilan bermain sepakbola baik, ada juga yang belum bisa melakukan permainan sepakbola. Dengan kata lain perbedaan ini dapat di istilahkan sebagai perbedaan kemampuan motorik yang dimiliki oleh siswa.

Siswa yang memiliki kemampuan motorik tinggi dengan siswa yang kemampuan motorik rendah idealnya tidak disamakan penanganannnya. Untuk dapat menjawab permasalah tersebut, penulis mencoba menerapkan pembelajaran pada kedua siswa yang memiliki perbedaan kemapuan tersebut. Adapun pembelajaran yang akan penulis coba terapkan adalah pembelajaran teacing game for understanding (TGFU) dan pembelajaran kooperatif.

Pembelajaran TGfU dalam penjas memfokuskan pada 
mengajar pemahaman taktis siswa sebelum berhubungan dengan kinerja keterampilan, dengan demikian TGfU ini menawarkan pendekatan taktis untuk mengajar kinerja game, menekankan game sebelum pertunjukan keterampilan Griffin, Mitchell, dan Oslin, (1997); Werner (1989) (dalam Hopper dan Darren Kruisselbrink (2002). Mengajar game yang efektif dari perspektif TGfU adalah tentang penggabungan ajaran pemahaman taktis dengan pengembangan keterampilan, dari pada berfokus pada satu aspek saja. Ide ini menyiratkan pengalaman bermain game untuk pendekatan mengajar permainan taktik - keterampilan. Griffin dkk, (1997) (dalam Hopper dan Darren, 2002). Menurut Butler (2005, p.1) "Teaching Games for Understanding (TGFU) is a learner and game centered approach to sport-related game learning with strong ties to a constructivist aproach to learning". Pembelajaran pendekatan taktik adalah sebuah pendekatan yang berpusat pada siswa dan permainan untuk pembelajaran permainan olahraga dan mempunyai hubungan yang kuat dengan sebuah pendekatan konstruktifistik dalam pembelajaran. TGFU sebagai sebuah alat untuk mengkonseptualisasikan

pengajaran dan pembelajaran permainan. Pembelajaran Pendekatan Taktik sangat mengutamakan peran guru sebagai fasilitator dan peran siswa untuk aktif dan terlibat dalam proses pembelajaran.

Sedangkan pembelajaran kooperatif lebih menekankan pada pendekatan pembelajaran yang berefektifitas yang mengintegrasikan keterampilan masing- masing individu. Pembelajaran kooperatif juga memfokuskan pada kegiatan siswa mempelajari keterampilan dasar dan memperoleh informasi yang dapat diajarkan selangkah demi selangkah. Menurut Juliantne (2011, hlm. 52) model pembelajaran kooperatif beranjak dari dasar pemikiran "getting better together" yang menekankan pada pemberian kesempatan belajar yang lebih luas dan suasana yang kondusif kepada siswa untuk memperoleh, dan 
mengembangkan pengetahuan, sikap, nilai, serta keterampilanketerampilan sosial bagi kehidupannya di masyarakat. "Menurut Eggen dan Kauchak Pembelajaran kooperatif merupakan sebuah kelompok strategi pengajaran yang melibatkan siswa bekerja secara berkolaborasi untuk mencapai tujuan bersama" (Julaintine, 2011, hIm. 52).

\section{B. Landasan Teori}

Dalam proses pembelajaran pendidikan jasmani, model pembelajaran merupakan salah satu rencana guru yang dilakukan untuk memberikan warna dalam proses penyampaian materi pendidikan jasmani. Sehingga proses pembelajaran akan semakin menarik dan disenangi oleh setiap siswa serta mempermudah guru dalam menyampaikan materi pendidikan jasmani. Model pembelajaran dipilih, digunakan dan disesuaikan dengan kondisi lingkungan belajar yang meliputi kadaan siswa, temapat belajar (prasarana), dan alat-alat (sarana) penunjang kegiatan belajar mengajar.

Menurut Husdarta dan Yudha (2000, hlm. 35) mengemukakan bahwa "model pembelajaran merupakan sebuah rencana yang dimanfaatkan untuk merancang pengajaran". Jadi model pembelajaran dalam diartikan sebagai rencana yang dibuat dan ditentukan oleh guru agar proses kegiatan belajar mengajar berjalan sesuai dengan apa yang diharapkan. Maka dari itu, guru sebagai pengajar harus terampil dalam menentukan model pembelajaran yang akan diterapkan. Sedangkan menurut Percipal (dalam Juliantine, 2011, hlm. 3) menyatakan bahwa: "Model is a physical or conceptual represntation of on object or system, incorporating certain specific features of the original". Model merupakan bentuk asli dari satu proses pembelajaran melainkan sebuah rancangan yang terdiri dari ciri yang khas.

1. Model Pembelajaran Teaching

Games for Understanding (TGfU) 
Model pembelajaran TGfU
pada pembelajaran penjas
memfokuskan pada mengajar
pemahaman taktis siswa sebelum
berhubungan dengan kinerja
keterampilan, dengan demikian

TGfU ini menawarkan pendekatan taktis untuk mengajar kinerja game, menekankan game sebelum pertunjukan keterampilan (Griffin, Mitchell, dan Oslin, 1997; Werner, 1989) dalam Hopper and Darren Kruisselbrink (2002).

Menurut Butler (2005, hlm. 1) "Teaching Games for Understanding (TGFU) is a learner and game centered approach to sport-related game learning with strong ties to a constructivist aproach to learning". Pembelajaran pendekatan taktik adalah sebuah pendekatan yang berpusat pada siswa dan permainan untuk pembelajaran permainan olahraga dan mempunyai hubungan yang kuat dengan sebuah pendekatan konstruktifistik dalam pembelajaran. TGFU sebagai sebuah alat untuk mengkonseptualisasikan

pengajaran dan pembelajaran permainan. Pembelajaran
Pendekatan Taktik sangat mengutamakan peran guru sebagai fasilitator dan peran siswa untuk aktif dan terlibat dalam proses pembelajaran.

2. Model Pembelajaran Kooperatif Model pembelajaran kooperatif yang didefinisikan oleh Metzler (2000, hlm. 221) sebagai berikut "...cooperative learning is not really a model by it self. It is a set of teaching strategies that share key attributes, the most important being the grouping of students into learning teams for set amounts of time or assigment with the expectation that all students will contribute to the learning process and outcomes". Dari kutipan diatas, model pembelajaran kooperatif merupakan pembelajaran yang ditandai dengan pengelompokkan siswa ke dalam beberapa kelompok belajar dalam waktu atau tugas-tugas tertentu, dengan harapan semua siswa akan berperan baik dalam proses maupun hasil belajarnya.

Semua anggota bekerja untuk mencapai tujuan yang sama. Model pembelajaran kooperatif merupakan salah satu model 
pembelajaran yang mendukung pembelajaran konstektual. Sistem pengajaran kooperatif dapat didefinisikan sebagai sistem kerja /belajar kelompok yang terstruktur. Yang termasuk di dalam struktur ini adalah lima unsur pokok menurut Jonson (Juliantine, 2011, hlm. 52), yaitu saling ketergantungan postitif, tanggung jawab individual, interaksi personal, keahlian bekerja sama, dan proses kelompok. Sehingga dengan diterapkannya model pembelajaran kooperatif ini diharapkan dapat meningkatkan hasil belajar dribbling dalam pembelajaran sepak bola. Dengan adanya proses pembelajaran kelompok ini siswa akan termotivasi untuk melakukan kegiatan pembelajaran secara maksimal.

3. Kemampuan Motorik

Motor ability atau kemampuan motorik lebih tepat disebutkan sebagai kapasitas dari seseorang yang berkaitan dengan pelaksanaan dan peragaan suatu keterampilan yang relatif melekat setelah masa kanak-kanak (Lutan, 2005, hlm. 105). Lebih lanjut, Schmidt \& Wrisberg (2000, hlm.
176) mengungkapkan bahwa: "Motor learning: change in internal processes that determine an individuals capability for producing a motor action. The level of an individuals motor learning improves with practice and is often inferred by observing relatively stable levels of the persons motor performance."

Pembelajaran motorik merupakan perubahan dalam proses internal yang membentuk kapasitas individu untuk menghasilkan gerak. Tingkat pembelajaran motorik individu meningkat dengan melakukan latihan dan sering disimpulkan berdasarkan observasi tingkat yang relatif stabil pada penampilan motorik seseorang. Lutan (1988, hlm. 96) mempertegas lagi tentang gambaran kemampuan motorik, yaitu bahwa pengaruh faktor biologis dianggap sebagai kekuatan utama terhadap kemampuan motorik dasar seseorang. Kemampuan motorik dasar itulah yang kemudian berperan sebagai landasan bagi perkembangan keterampilan. Sedangkan keterampilan banyak tergantung pada kemampuan 
dasar inilah yang nantinya akan berperan melaksanakan berbagai keterampilan olahraga.

\section{Metode Penelitian}

1. Lokasi dan Subjek Penelitian

a. Lokasi Penelitian

Lokasi merupakan tempat dimana penelitian tersebut akan dilakukan. Lokasi yang dipilih untuk dijadikan tempat penelitian ini adalah SMP Muhamadiyah Kecamatan Karangpawitan Kabupaten Garut, Propinsi Jawa Barat.

b. Subjek Penelitian

1) Populasi Penelitian

Populasi dan sampel merupakan bagian yang penting dari sebuah penelitian. Populasi merupakan individu atau subjek yang memiliki sifat-sifat umum. Dari populasi dapat diambil sejumlah data yang diperlukan untuk memecahkan suatu masalah yang diteliti. Dalam hal ini sugiyono (2010, hlm 80) menjelaskan sebagai berikut: "populasi adalah wilayah generalisasi yang terdiri dari atas obyek / subyek yang mempunyai kualitas dan karakteristik tertentu yang ditetapkan oleh peneliti untuk dipelajari dan kemudian ditarik kesimpulannya".

Sedangkan Riduwan (2004, hlm. 55) mengungkapkan bahwa: "Populasi merupakan objek atau subjek yang berada pada suatu wilayah dan memenuhi syaratsyarat tertentu berkaitan dengan masalah penelitian." Berdasarkan tiga pengertian di atas, maka populasi sasaran dalam penelitian ini adalah siswa kelas VIII SMP Muhamadiyah Karangpawitan, yang teridentifkasi memiliki tingkat kemampuan motorik rendah dan tinggi sebanyak 24 siswa dari populasi.

2) Sampel Penelitian

Pada hakekatnya sampel adalah orang atau tester yang akan diberikan perlakuan dalam sebuah penelitian. Dalam menentukan sampel Sudjana (2002, hlm. 6) menjelaskan bahwa, "sampel adalah bagian dari sebuah populasi yang dianggap dapat mewakili dari populasi tersebut". Maksudnya adalah sampel yang diambil untuk penelitian harus mewakili populasi penelitian. 
Dalam penelitian ini semua anggota populasi berjumlah 79 orang dapat dijadikan sebagai sumber data dan dapat pula hanya sebagian anggota populasi saja yang diambil sebagai sampel penelitian. Sehingga diperoleh sebanyak 48 orang yang akan dijadikan sampel dalam penelitian ini. Teknik pengambilan sampel dalam penelitian ini menggunakan teknik purposive random assignment.

Menurut Sugiyono (2010, hlm. 82) menjelaskan, "Pengambilan anggota sampel dari populasi dilakukan tanpa memperhatikan strata yang ada dalam populasi itu, cara demikian dilakukan apabila anggota populasi dianggap homogen". Jadi menurut pendapat diatas dapat disimpulkan bahwa pengambilan sampel dengan menggunakan teknik Random Assignment bukan berdasarkan stratata (tingkatan kelas), tetapi berdasarkan tingkatan kelompok kemampuan (general motor ability), untuk menentukan kelompok mana yang akan mendapat perlakuan dengan menggunakan model pembelajaran
Teaching

Games

for

Understanding

(TGfU)

dan

Kooperatif.

Adapun teknik pengambilan sampel yang digunakan sesuai dengan kebutuhan dan desain penelitian ini, langkah-langkahnya adalah sebagai berikut:

a) Seluruh sampel sebanyak 79 orang di tes kemampuan motoriknya dengan menggunakan Barrow Motor Ability Test.

b) Setelah mendapatkan data kemampuan motorik dari populasi tersebut, peneliti membuat daftar ranking dari pertama hingga akhir.

c) Kemudian penulis melakukan manipulasi kepada samperl dengan membagi ke 79 orang tersebut berdasarkan pendapat Verducci (1980, hlm. 176), yaitu diambil $27 \%$ kelompok atas dan $27 \%$ kelompok bawah, sesuai kebutuhan peneliti yang masingmasing berjumlah 24 siswa.

d) Dari masing-masing kelompok diatas dibagi 2 kelompok kecil dengan menggunakan teknik matching subjec dengan rumus ABBA dari urutan rangking 
paling atas. Sehingga diperoleh

4 kelompok kecil yang masingmasing berjumlah 12 orang. Dimana masing-masing kelompok tersebut dianggap memiliki kekuatan yang sama.

e) Dari masing-masing kelompok dirandom untuk diberikan perlakuan. (A) Model pembelajaran TGFU 24 orang yang terdiri dari 12 orang yang memilkiki kemampuan motorik tinggi dan 12 orang yang memiliki kamampuan motorik rendah, dan (B) Model Kooperatif 24 orang yang terdiri dari 12 orang yang memiliki kemampuan motorik tinggi dan 12 orang yang memiliki kemampuan motorik rendah.

2. Desain Penelitian

Desain penelitian yang digunakan adalah desain faktorial 2 $x$ 2. Menurut pendapat Fraenkel dan Wallen (1993, hlm. 255) bahwa: Another value of a factorial design is that it allows a researcher to study the interaction of an independent variable with one or more other variables, sometimes called moderator variables. Moderator variables may be either treatment variables or subject characteristic variables.

Maksud dari pernyataan di atas yaitu kelebihan lain dari desain faktorial adalah memungkinkan peneliti untuk mempelajari interaksi dari variabel lainnya, yang biasa disebut variabel moderator. Variabel-variabel moderator dapat berupa variabel perlakuan atau variabel karakteristik subjek.

\begin{tabular}{|c|c|c|}
\hline $\begin{array}{c}\text { Model } \\
\text { Kemampuan } \\
\text { Motorik }\end{array}$ & $\begin{array}{c}\text { TGfU } \\
\mathrm{A} 1\end{array}$ & $\begin{array}{c}\text { Kooperatif } \\
\mathrm{A} 2\end{array}$ \\
\hline TINGGI B1 & $\mathrm{A} 1 \mathrm{~B} 1$ & $\mathrm{~A}$ 2B1 \\
\hline RENDAH B2 & $\mathrm{A} 1 \mathrm{~B} 2$ & $\mathrm{~A} 2 \mathrm{~B} 2$ \\
\hline
\end{tabular}

Tabel 1 Kemampuan Motorik Keterangan:

A1 = Model pembelajaran TGfU

A2 = Model pembelajaran Kooperatif

B1 = Kemampuan motorik tinggi

B2 = Kemampuan motorik rendah

A1B1 = Model pembelajaran TGfU pada siswa yang mempunyai kemampuan motorik tinggi

A2B2 = Model pembelajaran Kooperatif pada siswa yang mempunyai kemampuan motorik rendah

A1B2 = Model pembelajaran TGfU pada siswa yang mempunyai kemampuan motorik rendah. 
A2B1 = Model pembelajaran

Kooperatif pada siswa yang mempunyai kemampuan motorik tinggi

\section{Metode Penelitian}

Penelitian ini menggunakan motode eksperimen. Penggunaan motode eksperimen ini disesuaikan dengan tujuan penelitian, yaitu ingin mengetahui hasil yang diujicobakan, sehingga hubungan sebab akibat antara kelompok yang satu dengan yang lainnya akan menjawab masalah penelitian yang diajukan. Seperti yang dikemukakan Arikunto (2002, hlm. 3) sebagai berikut:

Eksperimen adalah suatu cara untuk mencari hubungan sebab akibat (hubungan kausal) antara dua factor yang sengaja ditimbulkan oleh peneliti dengan mengeliminir atau mengurangi atau menyisihkan factor-faktor lain yang bisa mengganggu. McMillan \& Schumacer (1989) dalam Creswell (1994, hlm. 117) mengungkapkan: 'An experiment tests cause-and-effect relationships in which the researcher randomly assigns subjects to groups. The researcher manipulates on or more independent variables and determines whether these manipulations cause an outcome.' Maksudnya hubungan tes percobaan dengan metode sebab akibat dimana peneliti secara acak memberikan tugas kepada kelompok-kelompok. Peneliti memanipulasi satu variabel atau lebih dan menentukan apakah manipulasi ini menyebabkan suatu hasil. Berdasarkan ke tiga pendapat di atas, penelitian eksperimen adalah penelitian yang paling meyakinkan tentang variabel yang diteliti, karena dalam penelitian eksperimen peneliti memberikan perhatian serta kontrol penuh terhadap variabel yang dimanipulasi.

\section{Hasil Penelitian}

\section{Deskripsi Data}

Data hasil belajar keterampilan bermain sepakbola diperoleh dari hasil tes keterampilan dasar sepak bola (passing dan dribbling). Data yang digunakan untuk dianalisis yaitu dari hasil pre-test atau sebelum menggunakan model Teaching 
Games for Understading dan Cooperative

Learning.

Sedangkan data post-test diambil setelah selesai mengikuti proses pembelajaran yang menggunakan model pembelajaran Teaching Games for Understading dan Cooperative Learning. Sebelum menampilkan hasil pengolahan dan analisis data, peneliti menampilkan deskripsi data hasil penelitian sebagai berikut:

\section{a. Deskripsi Data Dengan Model Teaching Games for Understading}

Tabel 1 Data TGFU Motorik Tinggi

\begin{tabular}{|l|c|c|c|c|c|c|}
\hline \multirow{2}{*}{} & \multicolumn{2}{|c|}{ Passing } & \multicolumn{2}{c|}{$\begin{array}{c}\text { Dribbling } \\
\text { (detik) }\end{array}$} & \multicolumn{2}{c|}{ Gain } \\
\cline { 2 - 7 } & pre & pos & pre & pos & Passing & Dribbling \\
\hline Jumlah & 73 & 152 & 545 & 449 & 79 & 96 \\
\hline Rata-rata & 6.08 & 12.67 & 45.42 & 37.42 & 6.58 & 8.00 \\
\hline $\begin{array}{l}\text { Simpangan } \\
\text { Baku }\end{array}$ & 2.19 & 3.45 & 6.80 & 9.61 & 1.56 & 3.38 \\
\hline
\end{tabular}

Tabel di atas memberikan gambaran mengenai data hasil penelitian berdasarkan jumlah, rata-rata dan simpangan baku. Data passing dengan jumlah pretes 73, postes 152, rata-rata pretes 6,08, postes 12,67, Simpangan baku pretes 2,19 postes 3,45. Pada data dribbling dengan jumlah pretes 545 detik, postes 449 detik, ratarata pretes 45,42 detik, postes
37,42 detik. Simpangan baku pretes 6,80 dan postes 9,61.

Data TGFU Motorik Rendah

\begin{tabular}{|l|c|c|c|c|c|c|}
\hline \multirow{2}{*}{} & \multicolumn{2}{|c|}{ Passing } & \multicolumn{2}{c|}{$\begin{array}{c}\text { Dribbling } \\
\text { (detik) }\end{array}$} & \multicolumn{2}{c|}{ Gain } \\
\cline { 2 - 7 } & pre & pos & pre & pos & Passing & Dribbling \\
\hline Jumlah & 60 & 100 & 661 & 592 & 40 & 69 \\
\hline Rata-rata & 5.00 & 8.33 & 55.08 & 49.33 & 3.33 & 5.75 \\
\hline $\begin{array}{l}\text { Simpangan } \\
\text { Baku }\end{array}$ & 1.60 & 2.19 & 10.35 & 11.36 & 0.89 & 2.05 \\
\hline
\end{tabular}

Tabel $\quad 4.2 \quad$ tersebut memberikan gambaran data passing dengan jumlah pretes 60 , postes 100, rata-rata pretes 5, postes 8,33, Simpangan baku pretes 1,6 postes 2,19. Pada data dribbling dengan jumlah pretes 661 detik, postes 592 detik, ratarata pretes 55,8 detik, postes 49,33 detik. Simpangan baku pretes 10,35dan postes 11,36.

\section{b. Deskripsi Data Dengan Model}

\section{Cooperative Learning}

Data Cooperative Learning Motorik Tinggi

\begin{tabular}{|l|c|c|c|c|c|c|}
\hline \multirow{2}{*}{} & \multicolumn{2}{|c|}{ Passing } & \multicolumn{2}{c|}{ Dribbling (detik) } & \multicolumn{2}{c|}{ Gain } \\
\cline { 2 - 7 } & pre & pos & pre & pos & $\begin{array}{c}\text { Passin } \\
\text { g }\end{array}$ & Dribbling \\
\hline Jumlah & 70 & 124 & 569 & 490 & 54 & 79 \\
\hline Rata-rata & 5.83 & 10.33 & 47.42 & 40.83 & 4.50 & 6.58 \\
\hline $\begin{array}{l}\text { Simpangan } \\
\text { Baku }\end{array}$ & 1.95 & 2.57 & 12.99 & 14.98 & 1.73 & 2.23 \\
\hline
\end{tabular}

Tabel 3 memberikan gambaran data hasil tes passing pada siswa dengan motorik tinggi yang diberikan model Cooperative Learning. 
Dengan jumlah pretes 70 , postes 124 , rata-rata pretes 5,83 , postes 10,33, Simpangan baku pretes 1,95 postes 2,57 . Pada data dribbling dengan jumlah pretes 569 detik, postes 490 detik, rata-rata pretes 47,42 detik, postes 40,83 detik. Simpangan baku pretes 12,99 dan postes 14,98.

Tabel 4 Data Cooperative Learning Motorik Rendah

\begin{tabular}{|l|c|c|c|c|c|c|}
\hline \multirow{4}{*}{} & \multicolumn{2}{|c|}{ Passing } & \multicolumn{2}{c|}{$\begin{array}{c}\text { Dribbling } \\
\text { (detik) }\end{array}$} & \multicolumn{2}{c|}{ Gain } \\
\cline { 2 - 7 } & pre & pos & pre & pos & Passing & Dribbling \\
\hline Jumlah & 58 & 112 & 663 & 576 & 54 & 87 \\
\hline Rata-rata & 4.83 & 9.33 & 55.25 & 48.00 & 4.50 & 7.25 \\
\hline $\begin{array}{l}\text { Simpangan } \\
\text { Baku }\end{array}$ & 1.34 & 2.15 & 9.35 & 11.73 & 1.17 & 2.86 \\
\hline
\end{tabular}

Tabel 4 memberikan gambaran data hasil tes passing pada siswa dengan motorik rendah yang diberikan model Cooperative Learning. Dengan jumlah pretes 58 , postes 112 , rata-rata pretes 4,83 , postes 9,33, Simpangan baku pretes 1,34 postes 2,15. Pada data dribbling dengan jumlah pretes 663 detik, postes 576 detik, rata-rata pretes 55,25 detik, postes 48 detik. Simpangan baku pretes 9,35 dan postes 11,73.

2. Diskusi Temuan

a. Terdapat perbedaan hasil belajar keterampilan dasar sepakbola antara penerapan model pembelajaran dengan kemampuan motorik.

Hasil pengolahan dan analisis data membuktikan bahwa model pembelajaran dan kemampuan motorik dapat mempengaruhi secara signifikan terhadap hasil belajar keterampilan dasar sepakbola. Hasil pengolahan data menunjukan nilai $F=7,518$ dan sig $=0,000<0,05$ yang berbarti bahwa Terdapat perbedaan hasil belajar keterampilan dasar sepakbola secara keseluruhan antara penerapan model pembelajaran dengan kemampuan motorik. Seluruh data mengalami peningkatan berdasarkan pengambilan data pada pretes dan postes. Pada siswa yang diberikan model TGFU secara keseluruhan berdasarkan rata-rata hasil belajar mengalami peningkatan 50,6. Sedangkan pada Cooperative Learning secara keseluruhan berdasarkan rata-rata hasil belajar mengalami peningkatan 49,4. Berdasarkan motorik juga dapat dilihat peningkatan yang signifikan.

Pada siswa dengan motorik tinggi secara keseluruhan 
berdasarkan rata-rata hasil belajar mengalami peningkatan 53. Sedangkan untuk siswa dengan motorik rendah secara keseluruhan berdasarkan rata-rata hasil belajar mengalami peningkatan sebesar 47.

b. Terdapat pengaruh model pembelajaran terhadap hasil belajar keterampilan dasar sepakbola pada siswa dengan kemampuan motorik tinggi.

Hasil pengolahan data menunjukan nilai $\mathrm{F}=6,467 \mathrm{sig}=$ $0,019<0,05$ artinya terdapat pengaruh model pembelajaran terhadap hasil belajar keterampilan dasar sepakbola pada siswa dengan kemampuan motorik tinggi.

Rata-rata gain data hasil belajar siswa dengan kemampuan motoric tinggi berdasarkan model pembelajaran yang diberikan. Rata-rata gain hasil belajar siswa dengan model TGFU sebesar 57,22 . Sedangkan untuk rata-rata gain hasil belajar siswa dengan model Cooperative Learning sebesar 48,79. Data tersebut memiliki selisih yang cukup jauh, dimana pada siswa dengan kemampuan motoric tinggi ini peningkatan yang lebih tinggi adalah siswa yang mendapatkan model pembelajaran TGFU.

c. Terdapat pengaruh model pembelajaran terhadap hasil belajar keterampilan dasar sepakbola pada siswa dengan kemampuan motorik rendah.

Dalam pembahasan ini peneliti akan memaparkan mengenai hasil yang diperoleh melalui pengolahan dan analisis data pada siswa dengan kemampuan motoric rendah. Perbedaan perolehan hasil belajar rata-rata pada siswa dengan kemapuan motoric rendah. Perbedaan tersebut berbading terbalik dengan pembahasan sebelumnya. Pada siswa dengan kemampuan motoric tinggi model TGFU memiliki peningkatan yang lebih tinggi. Sedangkan pada siswa dengan kemampuan motoric rendah model Cooperative Learning memiliki peningkatan lebih tinggi. Grafik menunjukan peningkatan melalui model TGFU sebesar 43,99, sedangkan melalui model Cooperative Learning sebesar 50,01. Perbedaan tersebut 
memiliki niali yang cukup jauh, yakni sebesar 6,02.

d. Terdapat interaksi antara model pembelajaran dengan kamampuan motorik terhadap hasil belajar keterampilan dasar sepakbola.

Pengolahan dan analisis data dengan nilai $F=13,122$ sig $=0,001$ $<0,05$ artinya 1. Terdapat interaksi antara model pembelajaran dengan kamampuan motorik terhadap hasil belajar keterampilan dasar sepakbola.

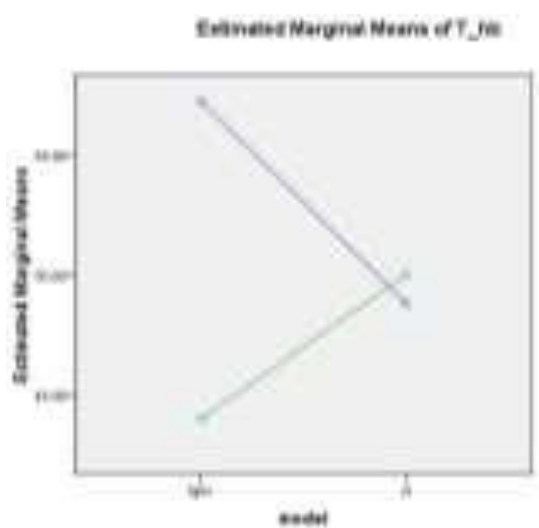

Grafik 1 Interaksi Model Pembelajaran dan Kemampuan Motorik Model pembelajaran

Teaching Games for Understading siswa diberikan kemudahan dalam bermain, disamping itu ada suatu kepercayaan diri siswa dalam belajar, apa yang menjadi permasalahan yang dirasakan siswa dalam permainan sepakbola.
Sedangkan Cooperative Learning merupakan model pembelajaran yang berlandaskan pada pemikiran "getting better together."

Model pembelajaran ini membuat siswa saling bekerja sama untuk menyelesaikan tugas belajar yang diberikan oleh guru. Mengamati, menganalisis dan memecahkan permasalahan secara bersamaan. Hal tersebut membuat siswa saling membantu satu sama lain, cenderung tidak membuat salah satu siswa menjadi yang paling atau lebih menonjol dari pada yang lainnya.

\section{E. Kesimpulan}

Berdasarakan hasil pengolahan dan analisis data yang telah dilakukan, dapat ditarik kesimpulan sebagai berikut:

1. Terdapat perbedaan hasil belajar permainan sepak bola secara keseluruhan antara penerapan model pembelajaran dengan kemampuan motorik.

2. Terdapat pengaruh model pembelajaran terhadap hasil belajar permainan sepak bola pada siswa dengan kemampuan motorik tinggi. Model 
pembelajaran teaching games for understanding memberikan pengaruh yang lebih tinggi dari pada model pembelajaran cooperative learning pada siswa dengan kemampuan motorik tinggi.

3. Terdapat pengaruh model pembelajaran terhadap hasil belajar permainan sepak bola pada siswa dengan kemampuan motorik rendah. Model pembelajaran cooperative learning memberikan pengaruh yang lebih tinggi dari pada model pembelajaran teaching games for understanding pada siswa dengan kemampuan motorik rendah.

4. Terdapat interaksi antara model pembelajaran dengan kamampuan motorik terhadap hasil belajar permainan sepak bola.

\section{DAFTAR PUSTAKA}

Arikunto, S (2002). Prosedur Penelitian, Suatu Pendekatan Praktek. Jakarta: PT Rineka Cipta. Hopper, Tim and Darren Kruisselbrink. (2002).
Teaching
Games
for
Understanding

(TGfU): What does it look like and how does it influence student skill learning and game performance?. [Online] tersedia

di http://web.uvic.ca/ thopper/ WEB/articles/Advante/TGFU motorlearn.pdf. Diakses 26 Februari 2015.

Husdarta dan Yudha, (2000). Belajar Dan Pembelajaran. Bandung : Depdiknas Juliantine, Tite dkk. (2011). Modelmodel Pembelajaran Pendidikan Jasmani. FPOK UPI. Bandung

\begin{tabular}{|c|c|c|}
\hline Lutan, & $\begin{array}{c}\text { Rusli (1) } \\
\text { keterampilan }\end{array}$ & 988) \\
\hline & Pengantar & Teori \\
\hline
\end{tabular}
Jakarta: Dirjen Dikti Depdikbud Metzler. M.W, (2000) Instructional Models For Psycal Education. Boston : Allyn and Bacon

Riduwan, (2004), "Metode dan Teknik Menyusun Tesis", Bandung: Alfabeta.

Sugiyono, (2010). Metode Penelitian Pendidikan 
Didaktik : Jurnal Pendidikan Guru Sekolah Dasar, ISSN : 24775673

Sekolah Tinggi Keguruan dan IImu Pendidikan Subang Volume III Nomor 1, Desember 2017

Kuantitatif Kualitatif R\&D.

Bandung: CV. Alfabeta

Verducci, Frank. M. (1989).

Measurment Concept in

Physical Education. St.

Louis: The C.C. Mosby

Company.

Butler. (2005). Teaching for game understanding theory, research, and practice. Illinois: Human Kinetics. 